\title{
Investigating Motivation for Learning Via Vroom's Theory
}

Asmidar Lokman, Farihah Hassan, Yus Aznita Ustadi, Farah Adilla Ab. Rahman, Zarina Mohd Zain, Noor Hanim Rahmat

To Link this Article: http://dx.doi.org/10.6007/IJARBSS/v12-i1/11749 DOI:10.6007/IJARBSS/v12-i1/11749

Received: 08 November 2021, Revised: 11 December 2021, Accepted: 28 December 2021

Published Online: 09 January 2022

In-Text Citation: (Lokman et al., 2022)

To Cite this Article: Lokman, A., Hassan, F., Ustadi, Y. A., Rahman, F. A. A., Zain, Z. M., \& Rahmat, N. H. (2022). Investigating Motivation for Learning Via Vroom's Theory. International Journal of Academic Research in Business and Social Sciences, 12(1), $504-530$.

\section{Copyright: (c) 2022 The Author(s)}

Published by Human Resource Management Academic Research Society (www.hrmars.com)

This article is published under the Creative Commons Attribution (CC BY 4.0) license. Anyone may reproduce, distribute, translate and create derivative works of this article (for both commercial and non0-commercial purposes), subject to full attribution to the original publication and authors. The full terms of this license may be seen

at: http://creativecommons.org/licences/by/4.0/legalcode

Vol. 12, No. 1, 2022, Pg. $504-530$

Full Terms \& Conditions of access and use can be found at http://hrmars.com/index.php/pages/detail/publication-ethics 


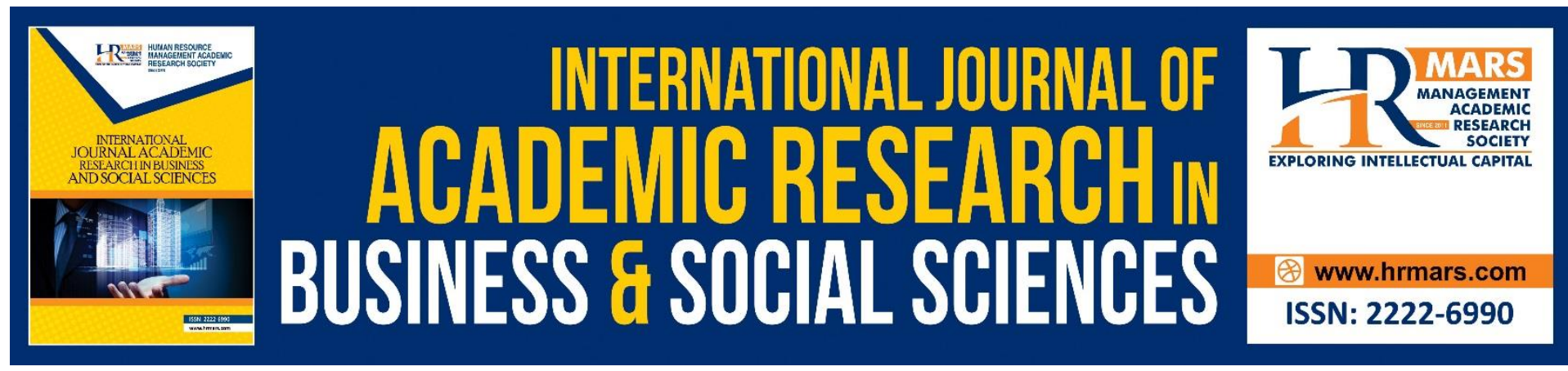

\title{
Investigating Motivation for Learning Via Vroom's Theory
}

\author{
Asmidar Lokman ${ }^{1}$, Farihah Hassan², Yus Aznita Ustadi ${ }^{3}$, \\ Farah Adilla Ab. Rahman ${ }^{4}$, Zarina Mohd Zain ${ }^{5}$, Noor Hanim \\ Rahmat $^{6}$ \\ 1,2,3,4,5Faculty of Administrative Science and Policy Studies, Universiti Teknologi MARA \\ ${ }^{6}$ Akademi Pengajian Bahasa, Universiti Teknologi MARA Cawangan Johor, Kampus Pasir \\ Gudang \\ Email: aslokman@uitm.edu.my,noorh763@uitm.edu.my
}

\begin{abstract}
The affective domain has been demonstrated to have a significant influence on student learning. This study examines the learning motivation of students within a higher education context. It introduces the definition of motivation and discusses the significance of motivation in learning. The existing research on motivation for learning is also discussed in light of Vroom's theory. The theory highlighting expectancy, instrumentality and valence is discussed in detail. Human motivation to learn outlines the underlying concepts of expectancy, affective and values are discussed. In doing so, this study explains that motivation for learning is influenced by students' low self-efficacy and control-belief that leads to them second guessing their true ability. Students too have lower affective response in learning motivation as they found taking tests is a daunting process. However, learning motivation is heightened when an extrinsic reward is targeted, and equally hard work is put on for the task that was assigned. The study adopted the quantitative approach where the survey is used as the research instrument. A questionnaire consisting of eight sections on demographic profile, motivation scale; values, expectancy and affective component were posed. The study found that students are highly motivated by extrinsic reward compared to intrinsic reward in their learning. Good grades are still the main attraction in the motivation to learn. However, students are found to be daunted by the thought and experience of going through learning sessions and sitting for assessments. This implies the need to embed more affective components into the curricula.
\end{abstract}

Keywords: Learning Motivation, Expectancy, Instrumentality, Valence

\section{Introduction}

\section{Background of Study}

Motivation is a complicated aspect of human psychology and behaviour that impacts how people choose to spend their time, how much energy they put into an activity, how they think and feel about it, and how long they stick with it (Bakar, 2014). Bakar indicates that students' motivation is reflected in their choices of learning tasks, the time and effort they dedicate to 
them, their perseverance on learning tasks, and how they deal with hurdles they face during the learning process. Besides that, motivation, as the name implies, gives students a goal to work for. It's a concept that explains why people act and think the way they do (Wlodkowski, 1999). These dimensions of motivation are supported by Brophy's motivational approach. "Motivation is a theoretical concept used to describe the initiation, direction, intensity, and persistence of behaviour, particularly goal-directed behaviour,". Student motivation is a term used in the classroom to describe the degree to which students devote their attention and effort to a variety of activities, which may or may not be those desired by the teacher."

In the perspective of education, students' level of motivation is expressed in their participation and involvement in the learning environment. Highly motivated students are frequently immersed in activities enthusiastically and spontaneously and find the learning process delightful without expecting any external rewards (Skinner \& Belmont, 1993). Students with poor motivation to study, on the other hand, may frequently rely on prizes to motivate them to participate in activities that they may not enjoy. Furthermore, the study done by Malone and Lepper (1987), there are few factors that lead to motivation. such factors are challenge, curiosity, control, fantasy, competition, cooperation, and recognition. All these factors can be categorized into extrinsic and intrinsic motivation. Extrinsic motivation, simply expressed, refers to people's willingness to do tasks and learn new abilities in exchange for external benefits or the avoidance of punishment. Meanwhile, the act of performing something without any visible external incentives is referred to as intrinsic motivation. You do it because you appreciate and find it interesting, not because of any other motivation or pressures, such as rewards or deadlines. In a nutshell, intrinsic motivation refers to doing something for the sake of doing it rather than for the reason of obtaining some external benefit or avoiding some external pressure. Essentially, the behaviour is a reward in and of itself.

\section{Statement of Problem}

In education, whether a person strives or fails in their education process depends importantly on how the student responds towards education challenges. Students' motivation regardless of whether intrinsic or extrinsic relate a lot to how students are engaged in the teaching and learning process. Research has been made and found that without proper support for the students, increasing standards for student learning heightens the risk that more students will fail and leave the educational system. (Dweck et al., 2011). Motivation is part of human behaviour and being a student, motivation is an important element to justify a quality learning.

Filgona et. al (2020) stated that for students to be motivated, the learning process must be based on four dimensions which are competence, control/ autonomy, interest/value, and relatedness. It was shown in the research by Saeed \& David (Year?) that motivation guides learners' interest into important learning activities, thus it is the teacher's responsibility to design a learning process that may attract students. Numerous research studies have shown that intrinsically motivated students have higher achievement levels, lower levels of anxiety and higher perceptions of competence and engagement in learning than students who are not intrinsically motivated (Wigfield \& Eccles, 2002; Wigfield \& Waguer, 2005).

Dislen (2013) found that the types and frequency of assessments influence the level of students' motivation and relate to poor performance in the learning process. Students lose 
their focus in the learning process and those with low motivation tend to not finish their homework. Wright (2011) also states that feelings of being unable to do the given tasks, less confident in learning and having deficient relationships or communication with lecturers also cause students to have low motivation. Generally, this research aims

- To identify learner's motivation.

- To examine expectancy influence on learner's motivation.

- To examine instrumentality influence on learner's motivation.

- To examine valence influence on learner's motivation.

Hence, this study is conducted to explore the influence of motivation on learners. Specifically, this study is done to answer the following research questions.

- How do expectancy component influence learner's motivation?

- How do instrumentality component influence learner's motivation?

- How do valence component influence learner's motivation?

\section{Literature Review \\ Expectancy Theory}

Motivational force is the force directing specific behavioural alternatives, which are suggested when deciding among behaviour options (Chiang \& Jang, 2008). The most comprehensive explanation on how an individual is motivated can be seen in Victor Vroom's expectancy theory (Vroom, 1964). The much earlier work of Tolman (1959) is at least part of the theoretical foundation on which Vroom's expectancy model is built. According to Tolman, expectancy theory assumes that we consciously make choices regarding the actions we take based on perceived outcomes associated with those actions and based on the perceived probability of obtaining the outcomes. Although the theory has its critics, most research evidence supports it (Eerde \& Thierry, 1996; Reinhart \& Wahba, 1975). The expectancy theory states that an individual tends to act in a certain way based on the expectation that the act will be followed by a given outcome and on the attractiveness of that outcome to the individual.

Expectancy theory provides a general framework for assessing, interpreting, and evaluating individual behaviour in learning, decision-making, attitude formation, and motivation (Chen and Lou, 2002). Expectancy theory is a theory of the process of motivation. Rather than simply explaining what will motivate an individual, process theories define how motivation comes about. Process theories are, in effect, working models of the decision-making processes that individuals perform to determine whether they will be motivated to pursue a certain activity and sustain a certain level of productivity. The motivational force for a behaviour, action, or task is a function of three distinct perceptions: expectancy, instrumentality, and valence.

Expectancy or effort-performance linkage is the probability perceived by the individual that exerting a given amount of effort will lead to a certain level of performance. Instrumentality or performance-reward linkage is the degree to which the individual believes that performing at a particular level is instrumental in attaining the desired outcome. Valence or attractiveness of reward is the importance an individual places on the potential outcome or reward that can be achieved on the task given. Valence considers both the goals and needs of the individual. 
Whether individuals are motivated to put forth effort (that is, to work hard) at any given time depends on the goals and perception of whether a certain level of performance is necessary to attain those goals. The key to expectancy theory is to understand an individual's goal and the linkage between effort and performance, between performance and rewards, and finally between rewards and individual goal satisfaction. It emphasizes rewards and excellence results. It believes that the rewards offered align with individuals' wants.

Expectancy theory recognizes that no universal principle explains what motivates individuals and thus stresses why individuals view certain outcomes as attractive or unattractive. After all, individuals should be rewarded with those things they value positively. Expectancy theory also emphasizes expected behaviours. The theory is concerned with perceptions. An individual's own perceptions of performance, reward and goal outcomes will determine his or her motivation or level of effort. The way in which the Expectancy theory works is as follows: An individual has personal goals which they like to achieve and for this reason they work hard to perform and get the best for the goals. These personal goals can be fulfilled by rewards or work outcomes. Therefore, the relationship between rewards or work outcomes and personal goals is important especially in finding out to what extent rewards fulfil the personal goals and how attractive are those rewards to that individual. This relationship can also be expressed as the value an individual gives to the work outcomes. Secondly, rewards or work outcomes are dependent on the individual performance. The level of belief that the individual employee has that his/her performance will result in achievement of personal rewards/work outcomes is also important. And thirdly, the perception of the chances by the individual that personal effort on his/her will lead to high performance is again important. Therefore, there are four variables for an individual that matter him/her in motivation. These variables are: 1 . Individual effort 2. Individual performance 3. Organizational rewards/work outcomes 4. Personal goals (Brent \& Polnick, 2012).

Several specific assumptions regarding students' performance need to be considered when utilizing expectancy theory in academia. These assumptions, according to Nadler and Lawler (1977), are as follows: (a) behaviour is determined by a combination of forces in the individual and forces in the environment, (b) people make decisions about their own behaviour, and (c) different people have different types of needs, desires and goals which can influence performance. Individuals, according to expectancy theory, make decisions to perform based on their perceptions of the likelihood that effort will lead to performance and performance will lead to desired outcomes (Vroom, 1964; Porter \& Lawler, 1968). Specifically, higher education students utilizing Vroom's theory would assume that "the choices made by a person among alternative courses of action are lawfully related to psychological events occurring contemporaneously with the behaviour". Overall, expectancy theory research supports the idea that individuals choose to alter inputs based on preferences among desired outcomes and the probability of attaining those outcomes at a satisfactory level. Studies have shown that each component of expectancy theory- expectancy, instrumentality, and valenceis an important factor in determining the extent to which an individual is motivated to increase or decrease productivity (Mitchell \& Biglan, 1971; Nadler \& Lawler, 1977; Porter \& Lawler, 1968; Vroom, 1964). 


\section{Affective Factors in Learning Motivation}

The affective domain in education covers the social and psychological aspect of learning. It asks the question of why our students learn. The domain is important yet is sometimes neglected or mostly overlooked by many (Pierre \& Oughton, 2007). The original formulation of affective learning by Krathwohl, Bloom and Masia (1964) characterised it as a subject matter learning on topics such as attending, responding, valuing, conceptualising, and characterising by value. Thus, the domains are attitude, values, feelings, and motivation. It aimed not only to gain specialised knowledge but also to achieve social ends (Lynch et al., 2009).

The first affective factor is attitude. It plays a substantial role in learning as it decides a favourable or unfavourable reaction towards learning a subject. A positive attitude determines positive learning behaviour (Guido, 2013) and has a significant effect on students' academic achievement (Abu Bakar et. al., 2010). The basic premise of Krathwohl taxonomy was intensity of given attitude is built through successive stages (Miller, 2005). Thus, learning involves attitude change which depends on what the person has learnt before. Theories of attitude change include behavioural, cognitive dissonance, affective-cognitive consistency, social judgment, social learning and functional. Behavioural theory explains that learning occurs when behaviour is positively reinforced. A cognitive dissonance theory explains that inconsistency between attitude and behaviour will create an unstable environment whereas an affective -cognitive consistency theory explains that attitude that is inconsistent with knowledge will create an unstable environment. The social judgment theory states that the existing attitude is surrounded by latitude of acceptance. Social learning theory is about an individual's attitude is learnt by observation and copying others' behaviour. Finally, functional theory explains that an individual determines the best method for changing his attitude to fit purposes. Attitude is an important affective component in learning motivation as it moulds the reaction of an individual towards learning.

The values component in the affective domain occupies a higher level of taxonomy in Bloom's. It marked the departure from the cognitive component of learning by addressing other important aspects of student learning (Lynch et al., 2009). This is because in learning, students learn how to express their feelings and emotions. Values influence their perception of things and represent their lifestyle. Valuing is about the ability to see the worth of something that one attached oneself with and the ability to express the worthiness. Therefore, the valuing component listed the level of acceptance of values, preference for a value and commitment to the values. It progresses from a simple to a complex acceptance of values. Values in the form of intrinsic and extrinsic motivation help in understanding the learning motivation. The valuing component deals more with the intrinsic value where emotions and feelings are key in learning motivation.

Interest is a component of affective domains which best predicts students' learning motivation (Harackiewicz et al., 2000). It jumpstarts a student's involvement in a task in which later self regulates the strategy and efficacy belief that is far more important than just 'steering' and controlling the actual performance (Wolters \& Pintrich, 1998). This shows that interest determines the intensity of student engagement in learning. Students who put values and interest in a task typically show greater persistence and effort in learning (Wigfield \& Eccles, 2002; Hidi \& Renninger, 2006). Their judgment on the difficulty of the task will be 
reflected in their response towards the task. Students with low task anxiety know what is expected out of the task compared to students who are unclear about the task will experience high task anxiety (McConnell \& van Der Hoven Kraft, 2011). Eventually, this will deter their ability to engage effectively in their learning tasks. Therefore, it is important that students develop self-regulation strategies such as planning of time and calculate the amount of time spent in both face to face and non-face to face learning sessions. This learning belief is likely to offer student success in adapting to other factors in learning (Alderman, 2008). A learning belief differentiates between students with intrinsic and extrinsic motivation. Students who are interested in the content of a subject are more engaged in learning compared to students who are grade focused who tend to succeed academically (Ryan \& Deci, 2000). Thus, having students who can combine both motivations will produce a well-rounded student of both cognitive and affective skills.

\section{The Influence of Value in Motivation among Learners}

In teaching-learning circumstances, motivation is a significant component. The motivation of the students determines the success of learning. Learners are motivated to achieve their learning objectives when they are motivated. Hence, the single most significant aspect of learning is the learners' motivation. Learning is intrinsically tricky; it requires the brain to be pushed to its limits, which can only be accomplished with incentive. Highly motivated students are more likely to learn quickly and make any class enjoyable to teach, whereas uninspired students are more likely to learn little and make teaching uncomfortable and stressful. Teachers cannot take learners' motivation for granted because contemporary education is obligatory, and they have a responsibility to guarantee that learners are driven to study. Teachers must encourage students to desire to do what is required of them (Filgona et al., 2020).

Noels et al. (1999) found that students' perceptions of teachers as autonomy-supportive and offering useful feedback can boost intrinsic motivation, which leads to better motivational intensity, self-evaluation of competence, and anxiety reduction. Intrinsic motivation has also been linked to lower anxiety, increased self-efficacy, and a positive attitude toward learning, according to Ehrman (in Katsuhisa \& Masahide, 2006). In addition, both intrinsic motivation and well-internalized (and thus autonomous) forms of extrinsic motivation predict a variety of positive outcomes across a range of educational levels and cultural contexts and that support students' basic psychological needs for autonomy, competence, and relatedness can help them achieve these goals (Ryan \& Deci, 2020).

Task values and learning goals release their full explanatory power as they affect students' concrete actions in each school subject, whereas basic achievement motives are equally essential at abstract and specific achievement levels. Task values and learning goals compete with more extrinsic types of motivation, such as performance goals, at this level of abstraction (Steinmayr et al., 2019)

A study by Dörnyei (1997) found that building group cohesiveness and having pleasant learning experiences are two excellent approaches to boost students' motivation in foreign language classes. The cohesiveness-performance effect can be especially powerful in language programmes where learners' communicative abilities are predominantly acquired by participation in real-world language tasks. Diverse forms of motivation, on the other hand, 
have different effects on learning experiences and outcomes. The extrinsic motivation was more challenging to understand than intrinsic motivation, resulting in mixed outcomes. Furthermore, learning experience had a moderating function in the relationship between motives and expanded social or civic participation, explaining only a portion of the relationship (Lai \& Hui, 2020).

Moreover, a favourable classroom climate increases learning and enhances academic performance (Ainley \& Ainley, 2011). In addition to enhancing student motivation and basic psychological needs; autonomy, competence, and relatedness (Martin et al., 2015).

Furthermore, educational psychologists have spent a lot of time looking into why some students are more motivated to study than others, as well as the elements that influence their academic behaviour. One of the primary methods to the study of academic motivation, expectancy-value theory (EVT), has been widely utilized to predict and explain students' task choices, learning perseverance, and academic success (Wigfield \& Eccles, 2000). According to the EVT theory, the higher the possibility of success, achievement, and perceived value in an activity, the more motivated learners will be to finish it. As a result, if the task is completed effectively, motivation and expectation beliefs will grow, and achievement will improve. As a result, decreased anxiety levels would help to boost motivated risk-taking behaviours and overall learning performance.

\section{Past Studies on What Demotivates Learners to Learn}

Learning is the process to modify the knowledge or attitude of the students. However, along the process, students are either motivated or demotivated in learning (Ngugi and Goosen, 2018). One of the factors that lead to demotivation of the learner is teacher-based factors such as attitude of the teacher, teaching competence, method of teaching and expertise of the teacher (Han, 2019). It is also supported by the study conducted by Ghadirzadeh et al (2013) revealed that teaching methods of the teacher contribute to demotivation among the Iranian university students. In addition, research done by Takase et al (2019) discovered when teachers gave unfavourable verbal and attitudinal messages to students or made a negative statement about them, their motivation to learn was compromised. The students were aware of what their lecturers said and what they meant.

Besides that, the students could tell whether the teachers were interested in them, involved in teaching, and passionate about it based on the teachers' teaching attitudes. If lecturers never glanced at their students during a lecture and the lecture was a one-way encounter, pupils would get the impression that their teachers were uninterested in them. Teachers who were hesitant to teach also transmitted a message that they were uninterested in doing so. Moreover, a study of Adaraa et. al (2019) provides a similar result as above whereby students are demotivated by teacher's competence and teaching style. Teachers appear to be an essential factor in students' demotivation, according to the findings, as they may play a role in supplying learning content and materials as well as affecting students' intrinsic motivation. Other factors contributing to the demotivation of the students to learn is the class atmosphere such as the attitude of the classmates and lack of facilities based on study by (Han et. al., 2019). It was also supported by Bekleyen in 2011 determined insufficient use of technical sorts of equipment, coursebooks, teaching methods, and teachers themselves are important issues that demotivate students. In addition, a study done by Ranjha et. al (2021) reveals that limited and poor educational amenities result in demotivation of students in 8 of 
the 44 studies. An unsuitable and unsporting school culture with insufficient facilities, like the classroom environment, has a detrimental impact on language learners' motivation. The classroom setting, as well as an unsuitable and unsporting school culture with restricted facilities, have a negative impact on language learners' motivation. Furthermore, Çankaya (2018) did a survey of 60 university students in Turkey and found that class characteristics and class environment were the most demotivating elements.

Further, Kim (2012) researched negative variables affecting Korean primary school kids' motivational trends using a mixed method study, and it was discovered that learning topics and materials, as well as test scores, are the key demotivating factors reported by Japanese students. The top three demotivating elements in learning, according to the findings by Ahmad (2021) are teachers who lecture too much, students who struggle to complete classwork, and learning activities that are not interesting enough to keep their attention. These variables moderately demotivated them in their learning.

\section{Motivations to Learn}

In a traditional learning environment, achievement goals and achievement goals orientation has been the major contribution towards learners' motivation. In psychological terms, goals are the subject, activity, or phenomenon at which our actions are directed and with which we satisfy our needs (Locke \& Latham, 1990). While achievement goals orientation can be related to an individual's general approaches with which they undertake tasks and evaluate their achievements (Ka- plan \& Maehr, 2007; Pintrich \& Schunk, 2002; Urdan, 2004). Thus, there is a need to look upon the achievement goals and achievement goals orientation that shall give high motivation to learners in education. Past research has indicated that to understand students' approach to studying or learning, it is important to understand their actions for dealing with certain tasks and the goals they set for themselves. For that matter, motivation is an internal state that arouses learners, steers them directions, and keeps them engaged in certain activities (Ormrod, 2008). Ormrod (2008) also explained that there are some factors that contribute towards college students in achieving goals and achieving goals orientation. Some students may learn the subject matter being presented in class, while others may be more interested in obtaining good grades, outperforming classmates, pleasing their instructors and parents, or simply completing assignments as quickly and painlessly as possible. This can be concluded that all these motivations have a desire to achieve certain learning outcomes. Intrinsic and extrinsic motivation are two major categories with which college students are engaged in the process of learning new knowledge and skills. Both types of motivation may not have the exact same effect on student learning and performance at the college level (Ormrod, 2008).

Jianzhong Xu (2021) looking into the phenomena of online assignment in higher education that presents significant motivational challenges for many online students. This is because little was known how online assignments affect students' behaviour and the reasons that motivate their learning performance. In the research, Jianzhong Xu (2021) aims to identify online assignment motivation profiles based on achievement goal theory (mastery- and performance approach goals) and expectancy-value theory (expectancy and value components). Volitional control has relevance to self-regulation of online assignment behavior, as the goals and expectations of online assignment are typically determined by online instructors (Boekaerts \& Corno, 2005), and as managing online assignment presents multiple volitional challenges (e.g., emotion, environment, and assignment; Corno, 2011). 
Particularly, it requires students to independently tackle the issues related to online assignment implementation and follow-through. It requires them to meet various selfregulatory demands associated with doing online assignment, including managing study environment, budgeting time, protecting concentration in the face of potential distraction, keeping themselves motivated, and regulating negative emotion (Corno, 1993; 2011; Xu et al., 2013; Xu et al., 2020).

Researcher looked upon self-regulated learning perspective, with volitional control, provides a comprehensive framework for studying online assignment behaviour (Boekaerts \& Corno, 2005; Corno, 1993, 2011; Ramdass \& Zimmerman, 2011). Based on the framework of volitional control (Boekaerts \& Corno, 2005; Corno, 2011), four studies have validated the Homework Management Scale (HMS) involving secondary students in U.S. and China (Xu, 2008a, 2008b; Xu, Fan, \& Du, 2015, Yang \& Xu, 2015). Results from these studies found that the HMS contained five factors - arranging the environment, managing time, handling distraction, monitoring motivation, and controlling emotion. Subsequent validation found that controlling emotion could be further distinguished into emotion management and cognitive reappraisal for secondary school students (Xu, Fan, \& Du, 2016) and college students with online assignments (Xu et al., 2018). On the other hand, whereas handling distraction could be further distinguished into handling conventional and tech-related distraction for secondary school students ( $\mathrm{Xu}, 2015)$, handling conventional and tech-related distraction were indistinguishable for college students with online assignment (Xu et al., 2020).

\section{Conceptual Framework}

During the process of learning, learners need to be engaged in meaningful learning. According to Abdul Wahid et al (2020), the feeling of connectedness gave learners a reason to stay motivated in the learning process. This study is rooted from the theories and concepts of (Vroom, 1964; Pintrich \& DeGroot, 1990). The three factors (expectancy, instrumentality and valence-figure 1) in Vroom (1964) are scaffolded onto Pintrich \& DeGroot (1990) three factors (expectancy, affective and value) and are shown in Figure 2.

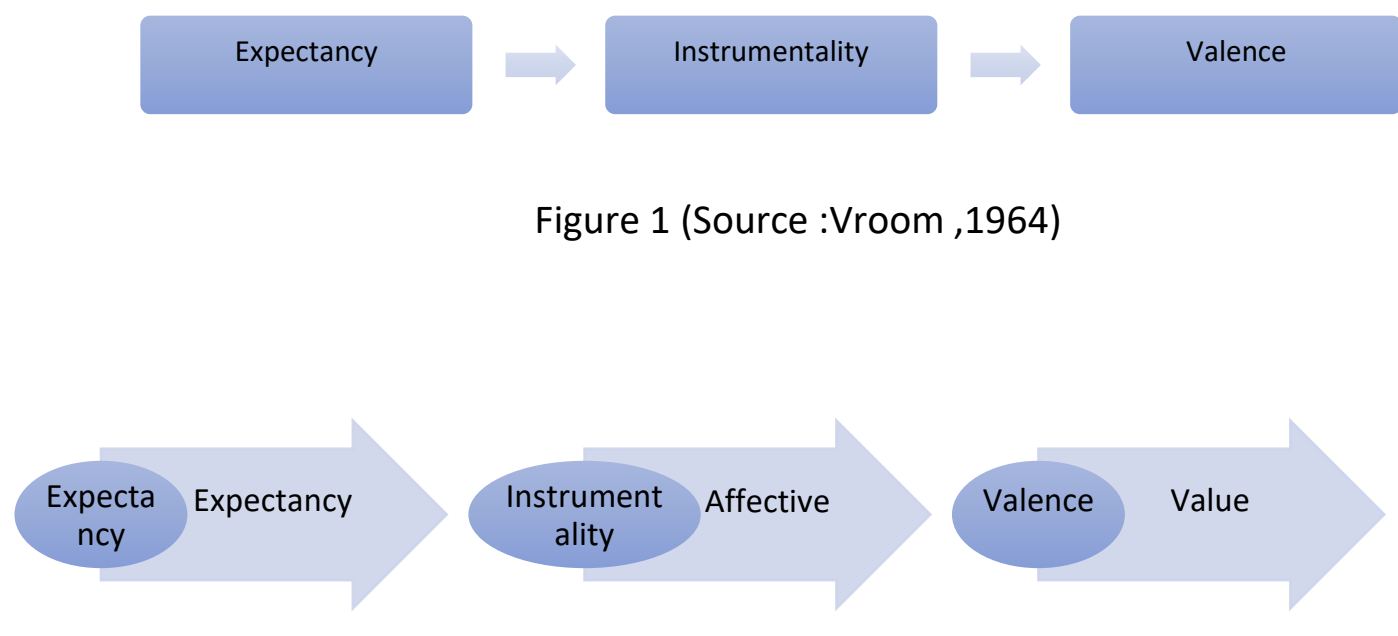

Figure 2- Conceptual Framework of the Study 
Hence the issue of motivation can be understood by understanding the characteristics. The past study enables the researcher to understand the issue and instruments used to research

\section{Methodology}

The phrase "research techniques" refers to a specific method of gathering and evaluating data. The researchers utilized quantitative research in this study. Questionnaires, surveys, polls, and other methods that transform data to numerical values are used quantitatively to obtain objective measurement and statistical data (Babbie, 2013). The researchers use quantitative approaches because they allow for the systematic definition of extensive collections of data.

\section{Research Design}

The general approach to this study is linked to the research design. The goal of research design is to create a study that enables the precise identification of independent and dependent variables. In addition, the research design refers to the approach for solving the research question. On the other hand, the researchers have employed a cross-sectional study rather than a longitudinal, experimental, or quasi-experimental study as a research design. The variables in this cross-sectional analysis are observed without attempting to change them (Cherry, 2019). Moreover, cross-sectional research allows for collecting data from many people and the examination of differences between them. Another benefit of cross-sectional research is that it saves time and effort because data may be collected at a single point in time.

\section{The Sample}

The sample size refers to the number of people or observations included in a study (Lavrakas, 2008). The letter " $n$ " is frequently used to represent this number. The sample size affects two statistical characteristics: the accuracy of our estimations and the research's capacity to conclude. The sample size is also referred to in which the researcher would pick the population for the study's aim (Sekaran and Bougie, 2016). Respondents in this study were students of semester one from two diploma programs, Diploma in Public Administration and Diploma in Corporate Administration, UiTM Seremban 3 campus. The sampling size was decided based on Krejcie \& Morgan (1970). Thus, the sample size, according to the table, should be about 70 respondents.

\section{Instrument}

The data collected used survey research where the instrument of questionnaire (table 1) was deployed to collect the data. The questionnaire consists of four sections with demographic profile and the components of affective learning which are values, expectancy, and affective components. 
Table 1- Motivational Scale (24 items)

\begin{tabular}{|l|l|l|l|l|l|l|}
\hline SECT & CONSTRUCT & & & VARIABLE & $\begin{array}{l}\text { No } \\
\text { Of Items }\end{array}$ & $\begin{array}{l}\text { Total } \\
\text { Items }\end{array}$ \\
\hline A & VALUE COMPONENTS & & (a) & Intrinsic Goal Orientation & 4 & 12 \\
\hline & & & (b) & Extrinsic Goal Orientation & 3 & \\
\hline & & (c) & Task Value Beliefs & 5 & \\
\hline & & & & & \\
\hline B & $\begin{array}{l}\text { EXPECTANCY } \\
\text { COMPONENT }\end{array}$ & (a) & $\begin{array}{l}\text { Students Perception of Self- } \\
\text { Efficacy }\end{array}$ & 7 \\
\hline & (b) & Control Beliefs for Learning & 2 & \\
\hline & & & & & \\
\hline C & AFFECTIVE COMPONENTS & & & 5 \\
\hline & TOTAL NO OF ITEMS & & \\
\hline
\end{tabular}

\section{Method of Data Collection}

The researchers in this study have chosen a quantitative method of measuring since the data can be quickly figured in graphs and statistical measurements. The most common quantitative data collection methods are surveys and questionnaires with closed-ended questions. The data for this study was gathered by the distribution of questionnaires via an online questionnaire. The most common approach for gathering data about people is to ask them questions and analyse their replies. Questionnaires, namely an online questionnaire (Google Forms), were used by the researchers. Online surveys are famous for this research because of their low cost and flexibility.

Furthermore, the researchers may access many samples regardless of time or location using an online survey. An online survey is a highly suggested approach when used in conjunction with the COVID-19 pandemic. The government issued a movement restriction order due to the epidemic, restricting interstate or inter-district mobility. As a result, the researcher chose an online survey as the data-gathering technique. The questionnaire was circulated via online platforms such as social media (WhatsApp, Facebook, Instagram, Twitter, and Telegram), and if necessary, the researcher utilized email as a secondary method of contact. The questionnaire also provides instructions for respondents to help them understand and finish it. The survey is multilingual, with portions written in both English and Malay. The goal is to make the questionnaire more user-friendly while also ensuring that respondents who do not understand English can complete it. As a result, once respondents have finished answering the question, they will submit the form to the researcher for analysis.

Moreover, because the objective of this research is solely academic, the information obtained through the online questionnaire will be kept confidential. In most cases, the respondent will be given a set amount of time to provide input for the subject. As a result, about 70 respondents from two diploma programs, Diploma in Public Administration and Diploma in Corporate Administration, engage in this study.

\section{Method of Data Analysis}

Sekaran (2009) elaborated that data analysis has three goals: establishing the meaning of the data, confirming the correctness of the data, and evaluating the hypotheses created for the study. Data analysis aims to describe how the approach was utilised to answer the research 
question and reach the objectives. In this study, the researchers used SPSS to analyse the data. The questionnaires (refer to table 2 ) are measured into nominal and ordinal scales.

Table 2. Measurement/ Instrument

\begin{tabular}{|l|l|l|l|}
\hline Variables & $\begin{array}{l}\text { Measurement/ } \\
\text { Observation }\end{array}$ & $\begin{array}{l}\text { Measuremen } \\
\text { t Scale }\end{array}$ & Type of Analysis \\
\hline Part 1 & Male or Female & Nominal & Descriptive analysis \\
\hline $\begin{array}{l}\text { Part 2 } \\
\text { Motivational }\end{array}$ & Value Component & Ordinal & $\begin{array}{l}\text { Descriptive Frequency } \\
\text { (Mean) }\end{array}$ \\
\cline { 2 - 5 } & $\begin{array}{l}\text { Expectancy } \\
\text { Component }\end{array}$ & Ordinal & $\begin{array}{l}\text { Descriptive Frequency } \\
\text { (Mean) }\end{array}$ \\
\cline { 2 - 5 } & $\begin{array}{l}\text { Affective } \\
\text { Component }\end{array}$ & Ordinal & $\begin{array}{l}\text { Descriptive } \\
\text { (Mean) }\end{array}$ \\
\hline
\end{tabular}

\section{Data Analysis}

Table 3- Reliability Statistics.

\section{Reliability Statistics}

\begin{tabular}{r|r}
$\begin{array}{c}\text { Cronbach's } \\
\text { Alpha }\end{array}$ & N of Items \\
\hline .873 & 24 \\
\hline
\end{tabular}

The researchers examine the reliability of structures by looking at the Cronbach's alpha coefficient to show how positive a group of systems is. Generally, reliability below 0.60 is considered flawed, those in the 0.70 range are considered acceptable, and those above 0.80 are considered good (Sekaran \& Bougie (2013). The Cronbach's alpha value for all 24 items was acceptable and reliable (0.873) (see table 3 ). 


\section{Findings}

\section{Findings for Demographic Profile}

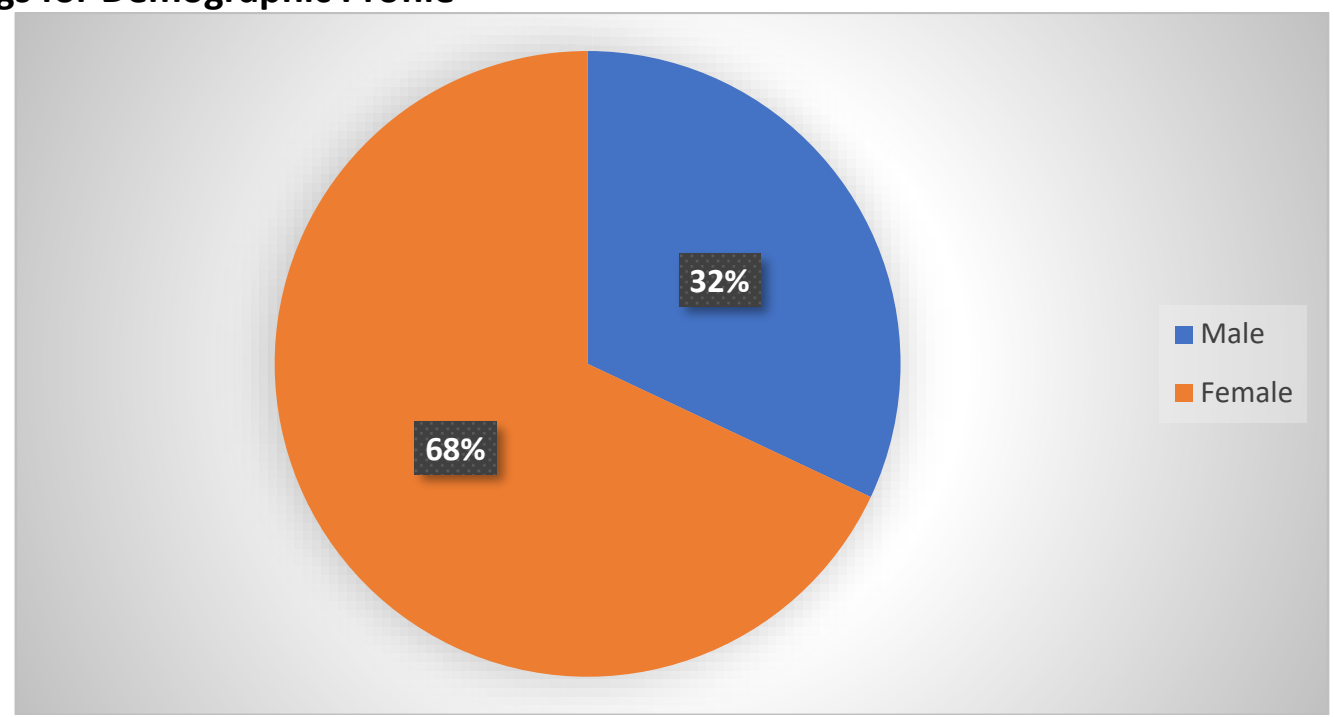

Figure 3-Percentage for Gender

The study has distributed questionnaires to 70 respondents who were Diploma students of part 1 during the academic session of March to August 2021. Based on the table above, most of the respondents who responded to the questionnaires were 48 females which represents $68 \%$ from total respondents. It was followed by 22 male respondents who answered the survey (refer to figure 3).

\section{Findings for Expectancy}

This section presents data to answer research question 1: How do expectancy components influence learner's motivation? There are two subcategories of expectancy components, and they are (a) students' perception of self-efficacy' and (b)control beliefs. 
(a) Students 'perception of self-efficacy

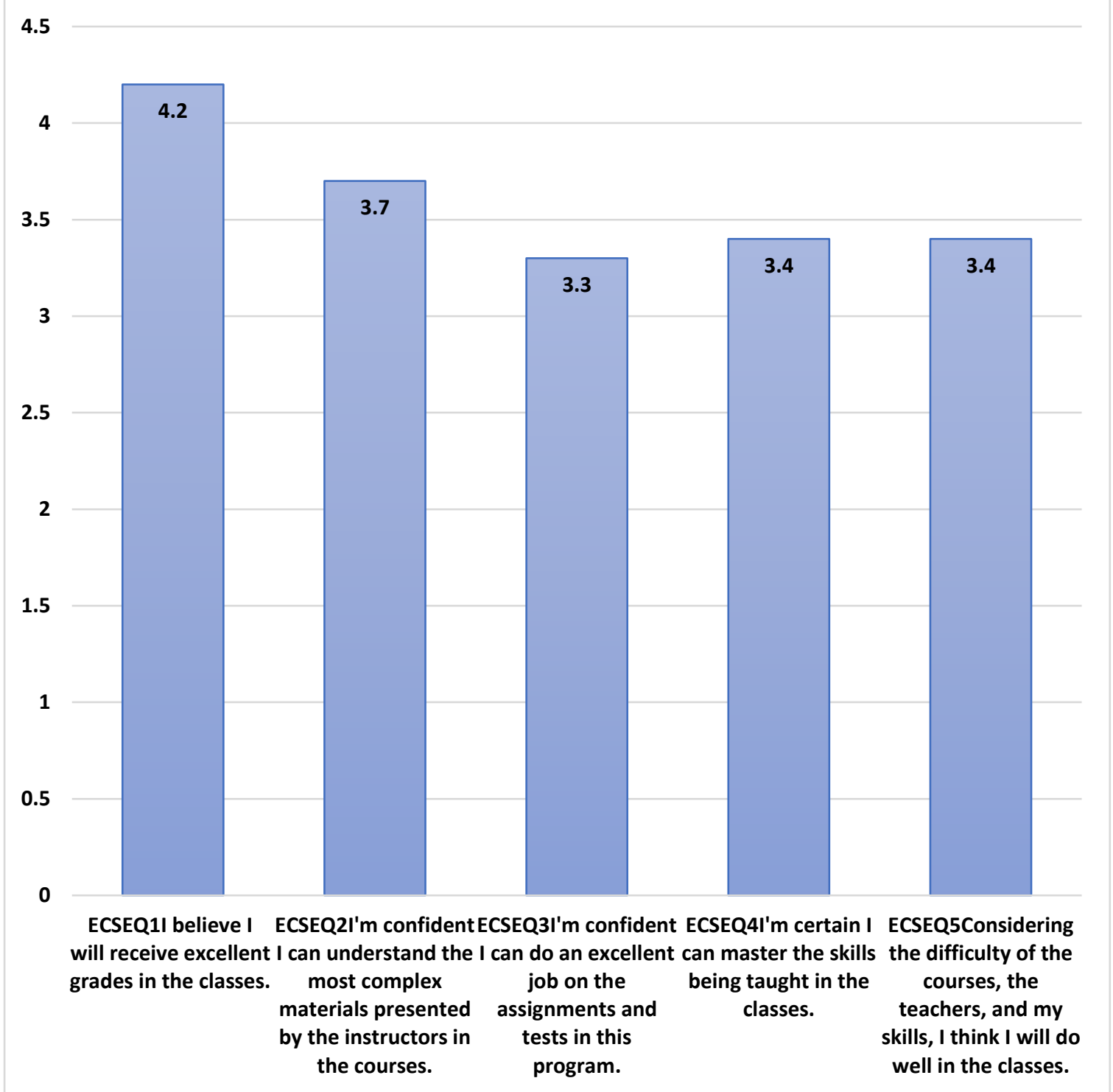

Figure 4-Mean for Students' Perception of Self-Efficacy

Expectancy components are divided into students' perception of self-efficacy and control beliefs for learning (figure 4). Students` perception of self-efficacy believed that they would receive excellent grades in the classes with a mean score of 4.2. Moreover, they are confident that they can understand the most complex materials presented by the instructors in the courses with a mean score of 3.7. Students are confident that they can master the skills being taught in the classes, and they will do well in the classes considering the difficulty of the courses, the teachers, and their skills with a mean score of 3.4. The least mean score is 3.3, in which students are confident they can do an excellent job on the assignments and tests in this program. 
INTERNATIONAL JOURNAL OF ACADEMIC RESEARCH IN BUSINESS AND SOCIAL SCIENCES

Vol. 12, No. 1, 2022, E-ISSN: 2222-6990 @ 2022 HRMARS

(b) Control beliefs for learning

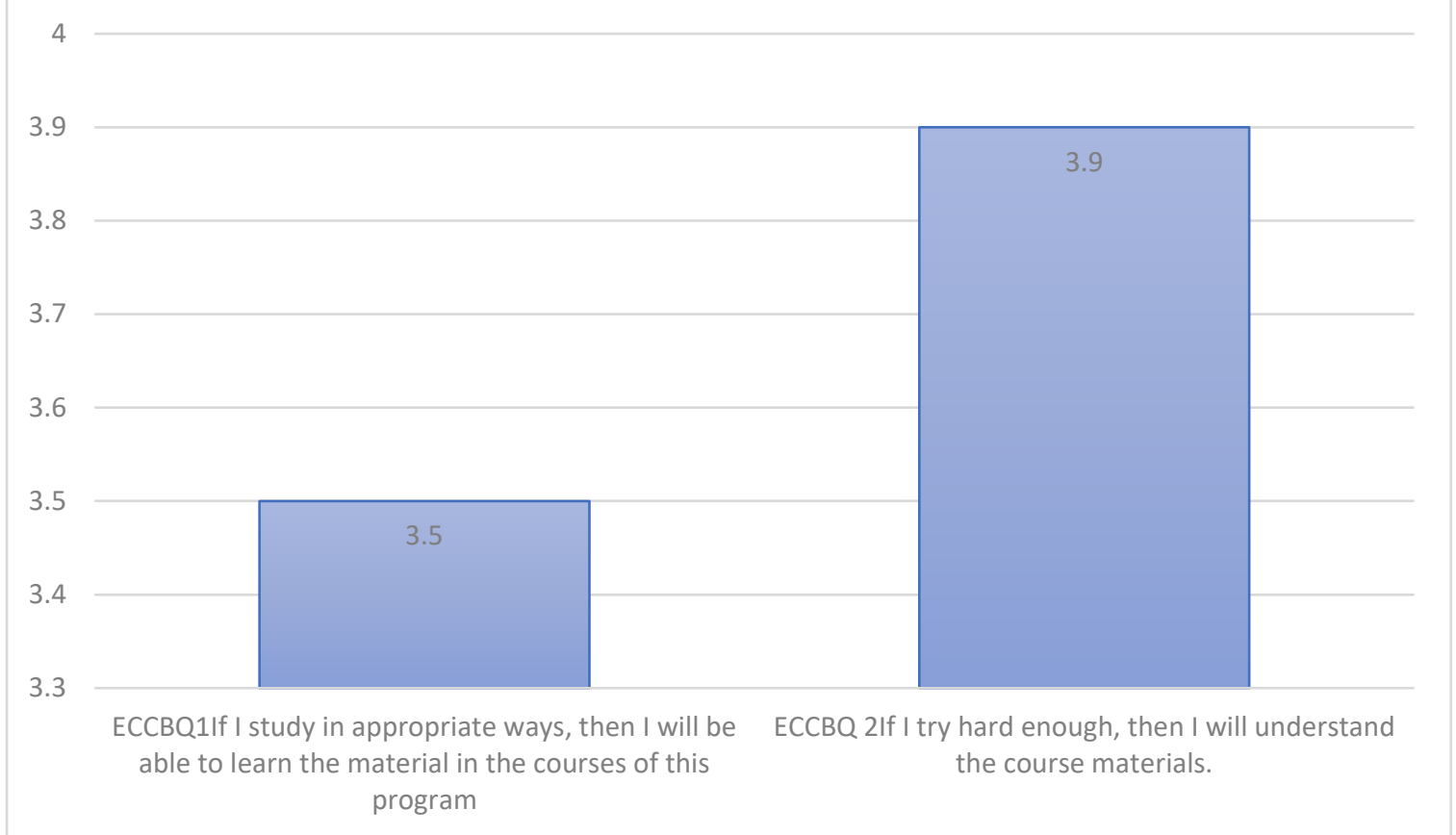

Figure 5- Mean for Control Beliefs

In control beliefs for learning (figure 5), students believe that if they try hard enough, they will understand the course materials with a mean score of 3.9. Meanwhile, the students believe that if they study appropriately, they will be able to learn the material in the courses of this program with a mean score of 3.5 . 


\section{Findings for Instrumentality through Affective Component}

This section presents the findings to answer research question 2: How do instrumentality components influence learner's motivation.

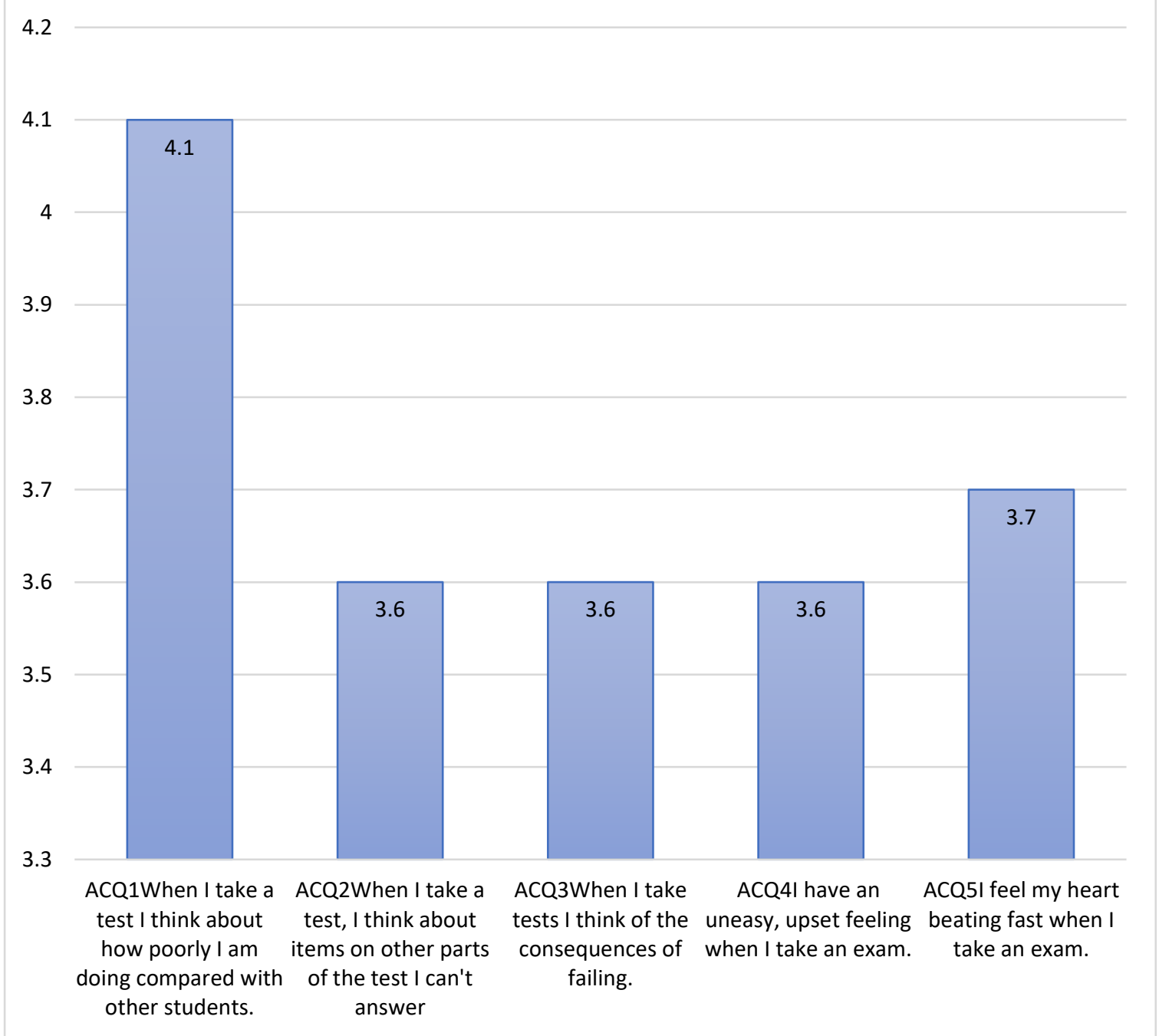

Figure 6- Mean for Affective Component

As stated by Smith \& Ragan (1999), affective learning outcomes involve attitude, motivation and values. It can be seen in the expressions involving statements of opinions, beliefs or assessment of worth. Thus, the findings from the survey showed, most of the respondents strongly believe that they were not good in assessment compared to their friends. And with a mean of 4.1 also showed that peers' pressure as what they believe may trigger strong motivation to do better.

Basically, most of the respondents believed the assessments taken were quite hard and they already developed an attitude towards predicting failures in the said assessment. This can be seen where a mean of 3.6 is associated with question 2,3 and 4 in Part C of affective components of motivation towards student learning process (refer to figure 6). 
The respondents also in the opinion that they were not confident during the test with a mean score of 3.7

\section{Findings for Valence through Value Components}

This section presents data to answer research question 3: How do valence components influence learner's motivation. Value components include (a) intrinsic goal orientation, (b) extrinsic goal orientation, and (c) task value beliefs.

(a) Intrinsic goal orientation

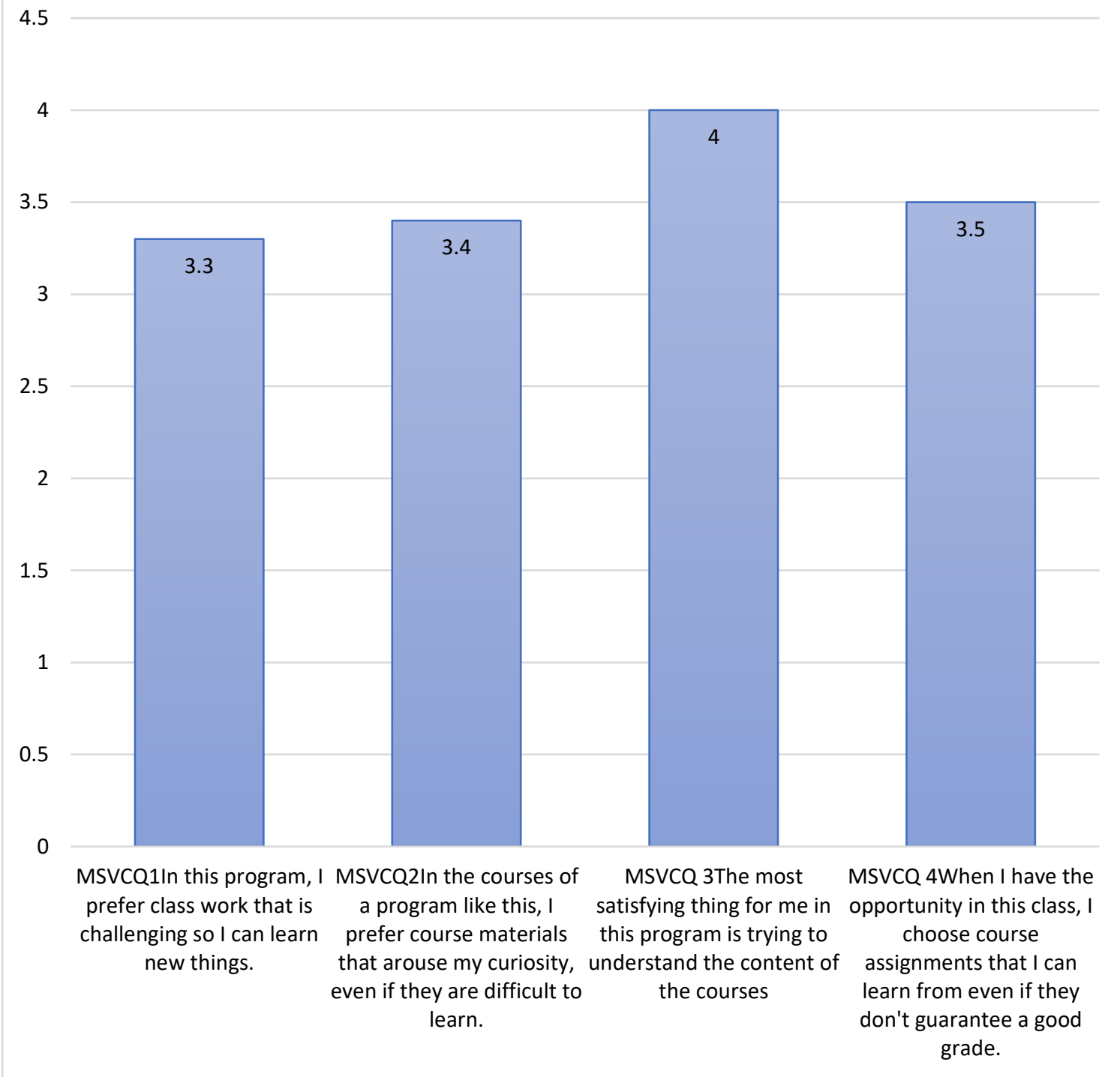

Figure 7-mean for Intrinsic Goal Orientation

Value component is divided into intrinsic and extrinsic goal orientation. In intrinsic goal orientation, the most satisfying thing for the students in this program is trying to understand the content of the courses with a mean score of 4 . Besides that, the student will choose the course assignment that they learn from even though there is no guarantee for a good grade with a mean score 3.5 (refer to figure 7). Moreover, the students prefer course material that arouses their curiosity even though it is difficult to learn with a mean score 3.4 . The least 
mean score 3.3 is the student's belief they can learn new things when the class work is challenging.

(b) Extrinsic goal orientation

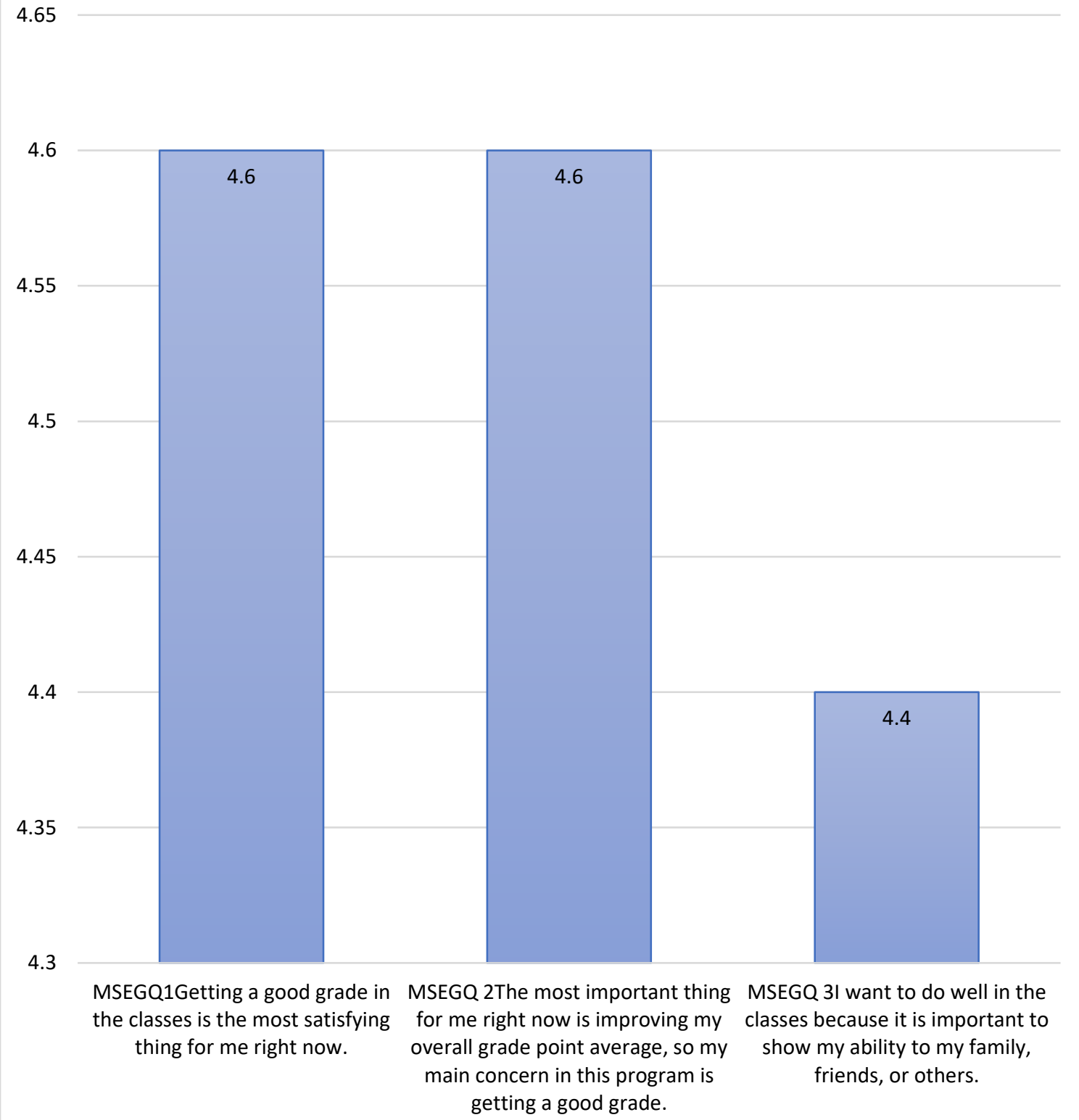

Figure 8- mean for Extrinsic Goal orientation

The findings in figure 8 show that getting good grades is the most satisfying for the student with the mean score of 4.6. This shows that extrinsic reward is very important to the students. Students are found to be focusing on improving their grade point average and made it their main concern reflected in the mean score of 4.6. Students are also found to view their ability in getting good grades in class as important to them. This success can be evidence to their family and friends of their ability to do well in their studies as shown in the mean score of 4.4. 
(c) Task value beliefs

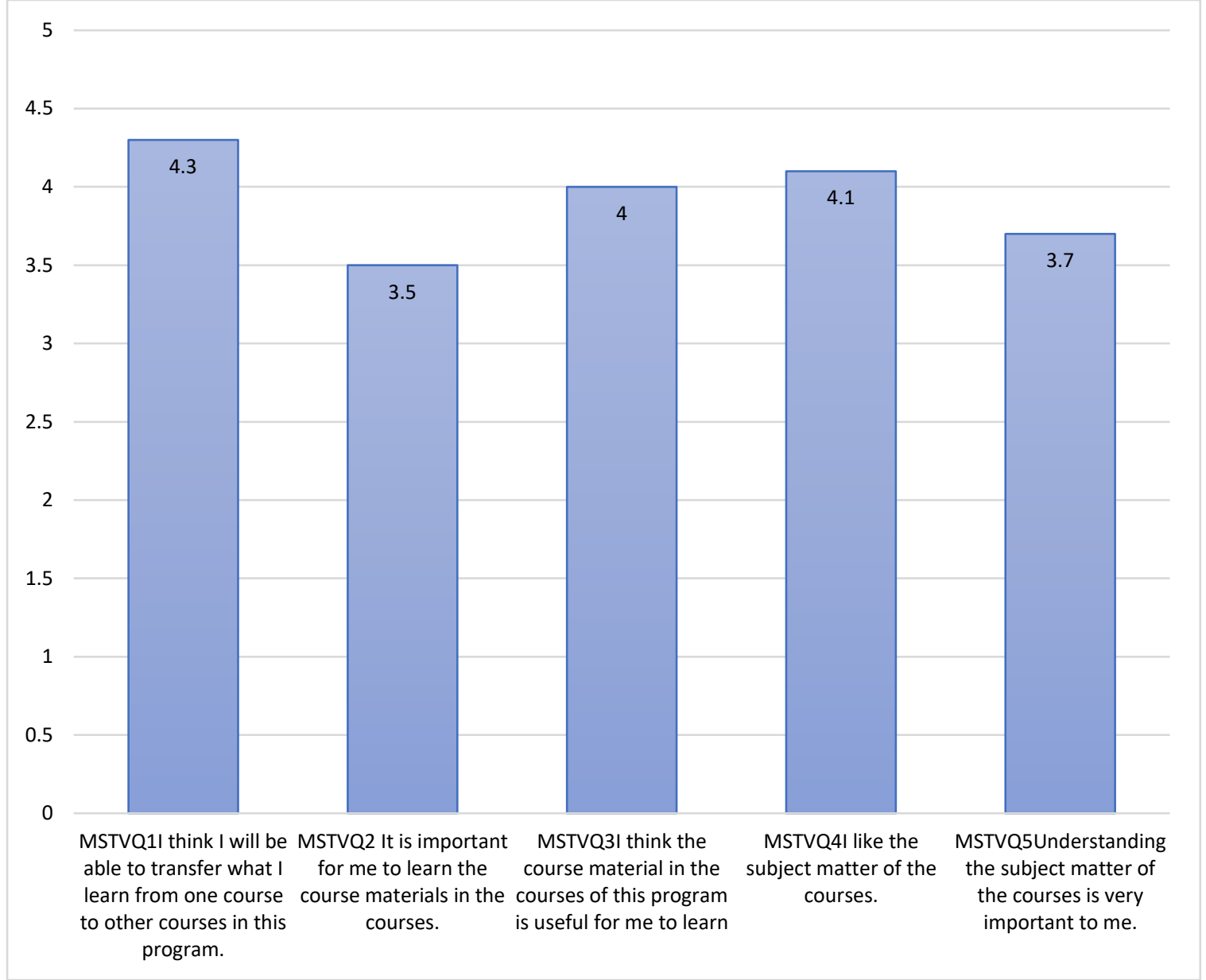

Figure 9- mean for Task Value Beliefs

Task value which focuses on affective memories is very important to increase the level of motivation for an individual. For this study (refer to figure 9), the level of motivation measures on the academic matters that focus on the task given. The expectation towards the task given will influence the level of motivation among students. From the findings, most of the students agree that a proper outline provided on the task to be done can help students well plan and well outline the task given. All those included in the course information given. Having clear information about the course through the materials given by the lecturer helps students to understand the courses (4.3) because the students like the subject matter of the courses (4.1) and focus on the courses since the course materials provided helps students a lot in mastery the syllabus well (4.0). The students also agree that understanding the subject matter is very important for teaching and learning (3.7) so that it's easy for the students to learn on the courses (3.5). Overall, expectation through providing proper guidelines and references can help students to study on the courses and this leads to highly motivation on learning.

\section{Summary of Findings and Discussion}

In investigating the motivation for learning, the component of value, expectancy and affective were tested to answer the research questions. The expectancy component of motivation in learning consists of students' perception of self-efficacy and control belief for learning. The result shows an interesting contrast to students' perception of self-efficacy. They believe that they can achieve excellent grades in class however the result showed a lower mean score on 
understanding complex learning materials. The result also showed that students are less confident in mastering skills taught in the class and have doubts in doing well in difficult subjects. A lower mean score on confidence of doing an excellent job in assignments and tests showed a somewhat baffling contrast to their positive perception in achieving good grades.

The valence component was tested by the intrinsic, extrinsic and task value beliefs to find out the motivational factor in learning. Both intrinsic and extrinsic goal orientations were found to be contributing factors to student motivation in learning though in varying degrees. Four items asked in the intrinsic goals have lower mean values than the extrinsic goals items. This indicates students put a higher importance on achieving extrinsic rewards. It corresponds to the expectancy aspect of the motivation. A student who works very hard will expect the outcome of scoring good grades. The grades thus become the main attraction to the motivation in learning despite facing hardship during the process (Bauer et al., 2016). These extrinsic rewards seekers contrasted to Skinner \& Belmont (1993) findings in which highly motivated students are delighted with the learning process without expecting external reward. However, the finding corresponds to what Skinner \& Belmont (1993) conclude that it is the poorly motivated students work hard in their learning, thus the expectation out of the effort is highly on getting extrinsic rewards. It is a way for them to stay motivated with their learning process by frequently relying on extrinsic rewards. Getting good grades is satisfying as it is usually linked with many other accolades such as the Dean's list and the Vice Chancellor's Award.

This established that students found it satisfying when their hard work is materialised in a physical form of a high cumulative grade point average. This aligns with the expectancy aspect of the learning motivation. Getting good grades is a reward that students value and expected from the effort they have put in. Good grades also become instrumental in students getting other extrinsic rewards such as continuing into a higher degree and university of their choice or getting better work pay if they choose to work after their studies. Good grades thus become attractive when students put high expectations onto the potential rewards that can be achieved by them putting effort into fulfilling their goals and needs at the same time.

In an Asian culture, getting good grades is important as it serves as a sign of intelligence, hard work and higher social prestige. Thus, in achieving this objective, students are willing to do and learn new things to gain extrinsic rewards or some do it just to avoid punishment or shame. The finding indicates that the motivation to learn is highly towards getting the extrinsic rewards rather than achieving the intrinsic rewards. The findings align with Ryan \& Deci (2000) finding that students who have extrinsic motivation focus more on succeeding academically compared to those who do not.

The task value beliefs result shows that students responded well to their tasks. The students are confident that they can transfer what they have learnt from one course to another. They also found that the course materials are helpful in learning. The finding shows that the students like the subject matter of the courses however find it difficult to understand. This shows that proper guidance and references in learning can assist students in their motivation to learn. The motivation to learn not only comes from the students' effort but also comes 
from the support that they need in learning. This will increase the motivation in learning as the students can relate to the possibility of success and achievement.

An affective component was tested, and the result showed that students expressed a low belief on their ability in taking and performing in examinations. They are found to always compare themselves with their friends. However, peer pressure becomes a catalyst in doing better in learning. Nevertheless, students are found to have lower confidence while sitting for a test and can see themselves failing while answering the test that they sit for. Students found the worth of success in examinations in terms of getting good marks but not in terms of self-development. Due to the high orientation on result-based success, the values of effort, hard work, commitment, and perseverance are not considered as worthy to be proud of from a learning experience. Somehow this flawed the affective component of learning which aimed at students' ability to identify their feelings, emotions and interest and use them as an advantage in learning beyond achieving good grades.

\section{Pedagogical Implications and Suggestions for Future Research}

Students' motivation is important for a good teaching learning process since it impacts selfengagement and classroom participation. To fulfil the teaching aim and offer a relevant learning process for the students, the instructor must first encourage the students' motivation. Students' learning and conduct are influenced by motivation in a variety of ways. Motivation, for starters, leads behaviour toward specific goals. Motivation influences the decisions pupils make since it establishes the exact goals for which they strive. Increased effort and energy are also a result of motivation. Motivation influences whether a learner will approach a task (even one that is tough) with zeal or with a sour attitude. Therefore, motivation is an essential tool for today's student and educator. A responsive teacher's role and responsibility is to ensure that the students are adequately educated. Only when both the teachers and the students are motivated can teaching and learning be successful.

Since the respondent in this study only focuses on first year diploma students in the Faculty of Administrative Science and Policy Studies, Universiti Teknologi MARA, Malaysia, it is suggested for future research to be conducted at the degree and postgraduate level at other faculty either in public or private academic institutions. This is to investigate for any similarities or differences based on the level of thinking, maturity, and expectation (interest and need) of this category of students which vary accordingly.

\section{References}

Adaraa, R. A., Nuryadia., and Nasutiona, R. A. (2019). Investigating the difference in demotivation factors: A case study of two groups of Indonesian EFL learners. Journal of English Language Studies.4(2), 212-225. https://pdfs.semanticscholar.org/0e3f/08bc4564765af36ec8830e5c705766a6df0c.pdf

Ahmad, C. V. (2021). What makes our students demotivated in learning? Indonesian Journal Of Educational Research and Technology, 1(2), 51-56. http://dx.doi.org/10.\%2017509/xxxxt.vxix

Ainley, M. D., \& Ainley, J. (2011). Student engagement with science in early adolescence: the contribution of enjoyment to students' continuing interest in learning about science. Fuel and Energy Abstracts. Retrieved from https://www.semanticscholar.org/paper/Student-engagement-with-science-in-early\%3A-the-of-Ainley-Ainley/ab87301fb6a1e653da3a1a0f3619899bbc6882db 
Babbie, E. (2013). The practice of social research. (13th ed.). Belmont: Wadsworth. Retrieved from https://www.amazon.com/Practice-Social-Research-13th/dp/1133049796

Bauer, K. N., Orvis, K. A., Ely, K., \& Surface, E. A. (2016). Re-examination of motivating in learning contexts: Meta-analytically investigating the role type of motivation plays in the prediction of key training outcomes. Journal of Business and Psychology, 31(1): 3350. https://doi.org/10.1007/s10869-015-9401-1

Brent, E., \& Polnick, B. (2012). Examining Motivation Theory in Higher Education: An Expectancy Theory Analysis of Tenured Faculty Productivity. International Journal of Management, Business, and Administration, volume 15, number 1, 2012. http://www.nationalforum.com

Brophy, J. (1998). Motivating students to learn. United States of America: McGraw-Hill.

Cankaya, P. (2018). Demotivation Factors in Foreign Language Learning. Journal of Foreign Language Education and Technology, 3(1), 2018.

Retrieved from https://www.researchgate.net/publication/321938577

Chiang, C. F., \& Jang, S. S. (2008). An expectancy theory model for hotel employee motivation. International Journal of Hospitality Management 27 (2008) 313. https://www.journals.elsevier.com/locate/ijhosman

Chen, Y., \& Lou, H. (2002). Toward an understanding of the behavioral intention to use a groupware application. Journal of End User Computing 14, 1-16. https://www.researchgate.net/publication/314671520

Cherry, K. (2019). How does the cross-sectional research method work? Retrieved from https://www.verywellmind.com/what-is-a-cross-sectional-study-2794978

Christophel, D., \& Gorham, J. (1995). A test-retest analysis of student motivation,teacher immediacy and perceived sources of motivation and demotivation in college classes. Communication Education, 44, 292 - 306. https://doi.org/10.1080/03634529509379020

Dörnyei, Z. (1997). Psychological processes in cooperative language learning: Group dynamics and motivation. The Modern Language Journal, 81(4), 482-493. doi:10.1111/modl.1997.81.issue-4. Retrieved from https://onlinelibrary.wiley.com/doi/abs/10.1111/j.1540-4781.1997.tb05515.x

Dörnyei, Z. (2001). Motivational strategies in the language classroom. UK: Cambridge University Press. https://doi.org/10.1017/CB09780511667343

Dweck, C. S., Walton, G. M., \& Cohen, G. L. (2011). Academic tenacity (White paper prepared for the Gates Foundation). Seattle, WA: Gates Foundation.

Eerde, W. V., \& Thierry, H. (1996). Vroom's expectancy models and work-related criteria: A meta-analysis. Journal of Applied Psychology, pp. 578-586.

https://www.researchgate.net/publication/232565056_Vroom's_expectancy_models _and_work-related_criteria_A_meta-analysis

Filgona, J., Sakiyo, J., Gwany, D. M., \& Okoronka, A. U. (2020). Motivation in learning. Asian Journal of Education and Social Studies, 10(4), 16-37. https://doi.org/10.9734/ajess/2020/v10i430273.

Gorham, J., \& Christophel, D. (1992). Students' perception of teacher behaviors as motivating and demotivating factors in college classes. Communication Quarterly, 40, 239- 252. https://citeseerx.ist.psu.edu/viewdoc/download?doi=10.1.1.981.1322\&rep=rep1\&typ $\mathrm{e}=\mathrm{pdf}$ 
Gorham, J., \& Millette, D. (1997). A comparative analysis of teacher and student perceptions of sources of motivation and demotivation in college classes. Communication Education, 46, 245 - 261. https://doi.org/10.1080/03634529709379099

Guido, R. M. D. (2013). Attitude and motivation towards learning physics. International Journal of Engineering Research and Technology, 2(11), 2087-2094. ISSN:2278-0181

Ghadirzadeh, R., Hashtroudi, F. P., \& Shokri, O. (2013). Study of the effective factors on the university students' underachievement in English language learning. English Language Teaching, 6(11), 122-129. https://eric.ed.gov/?id=EJ1078455

Han, T., Tulgar, A. T,. and Aybirdi, N. (2019). Factors causing demotivation in EFL learning process and the strategies used by Turkish EFL learners to overcome their demotivation. Advances in Language and Literary Studies. http://dx.doi.org/10.7575/aiac.alls.v.10n.2p.56

Harackiewicz, J. M., Barron, K. E., Tauer, K. M., Carter, K. M., \& Elliot, A. J. (2000). short term and long-term consequences of achievement goals: Predicting interest and performance over time. Journal of Educational Psychology, 92, 316-330. Retrieved from researchgate.net/profile/Kenneth-Barron/publication/283949755_Short-

term_and_Long-

term_Consequences_of_Achievement_Goals_Predicting_Interest_and_Performance_ over_Time/links/59ef487e458515ec0c7b5935

Jianzhong, Xu. (2021). A profile analysis of online assignment motivation: Combining achievement goal and expectancy-value perspectives, , Computer \& Education. 177. https://doi.org/10.1016/j.compedu.2021.104367 Received 14 April 2021;

Jomairi, S. (2011). Demotivating factors in second language learning at State, Azad, and Payam-Nour Universities, International Conference on Languages, Literature and Linguistics, IACSIT Press. Singapore.

Katsuhisa, H., \& Masahide, S. (2006). New orientations in language learning motivation: Intrinsic/extrinsic motivation and self-determination theory. Kyouka Kyouiku Gakuronshuu, 3, 37-48. Retrieved from https://www.semanticscholar.org/paper/NewOrientations-in-Language-Learning-Motivation-\%3A-HondaSakyu/282f3866dd5ceb8426cb5baa3c09a19d1d64f49c

Kim, T. Y. (2012). Elementary school students' foreign language learning demotivation: A mixed methods study of Korean EFL context. The Asia Pacific Education Researcher, 21(1), 160-171. retrieved from https://www.researchgate.net/publication/312449515_EFL_learning_demotivation_in _the_Korean_context_Similarities_and_differences_across_school_levels

Krathwohl, D. R., Bloom, B. S., \& Masia, B. B. (1964). Taxonomy of educational objectives: Handbook 2: The affective domain. London: Longmans, Green and Co Ltd.

Krejcie, R.V., \& Morgan, D. W. (1970). Determining Sample Size for Research Activities. Educational and Psychological Measurement.Retrieved from https://home.kku.ac.th/sompong/guest_speaker/KrejcieandMorgan_article.pdf

Lai, S. Y., \& Hui, C. L. (2020). Service-learning: Impacts of learning motivation and learning experience on extended social/civic engagement. Higher Education Research and Development, 1-16. https://doi.org/10.1080/07294360.2020.1756748

Lavrakas, P. J. (2008). Encyclopedia of survey research methods (Vols. 1-0). Thousand Oaks, CA: Sage Publications, Inc. doi: 10.4135/9781412963947. Retrieved from https://methods.sagepub.com/reference/encyclopedia-of-survey-researchmethods/n507.xml 
Lei, S. A. (2010). Intrinsic and Extrinsic Motivation: Evaluating Benefits and Drawbacks from College Instructors' Perspectives, Journal of Instructional Psychology, 37(2):153-160. http://doughertyconsulting.com/Psychology_Course_Resources/documents/Motivati on\%20and\%20Learning\%20Articles/Intrinsic\%20and\%20Extrinsic\%20Motivation\%20a nd\%20Learning.pdf

Lynch, D. R., Russell, J. S., Evans, J. C., \& Sutterer, K. G. (2009). Beyond the cognitive: The affective domain, values and the achievement of the vision. Journal of Professional Issues in Engineering Education and Practice, 135 (1), 47-56. https://doi10.1061/(ASCE)1051-3928 (2009) 135,1(47)

Malone, T. W., \& Lepper, M. R. (1987). Making learning fun: A taxonomy of intrinsic motivations for learning. In R.E. Snow \& M.J Farr (Eds.), Aptitude, learning, and instruction volume 3: Cognitive and affective process analyses. 223-253. Hillsdale, NJ: Lawrence Erlbaum Associates, Publishers.

Martin, A. J., Papworth, B., Ginns, P., \& Malmberg, L. E. (2015). Motivation, engagement, and social climate: An international study of boarding schools. Journal of Educational Psychology.1-15. Retrieved from https://www.researchgate.net/publication/284217921_Motivation_Engagement_and _Social_Climate_An_International_Study_of_Boarding_Schools

Miller, M. (2005). Teaching and learning in affective domain. In M. O Refy (Ed.) Emerging perspectives on learning, teaching and technology. Retrieved from http://epltt.coe.uga.edu/

Mitchell, T. R., \& Biglan, A. (1971). Instrumentality theories: Current issues in psychology. Psychological Bulletin, 76, 432-454.

Nadler, D. A., \& Lawler, E. E. (1977). Motivation: A diagnostic approach. In J. R. Hackman, E. E. Lawler, \& L. W. Porter (Eds.), Perspectives on behavior in organizations (pp.26-34). New York, NY: McGraw-Hill.

Ngugi, J., and Goosen, L. (2018). Modelling course-design characteristics, self-regulated learning and the mediating effect of knowledge-sharing behavior as drivers of individual innovative behavior. EURASIA Journal of Mathematics, Science and Technology Education, 14(8), 1-18.http://dx.doi.org/10.29333/ejmste/92087

Noels, K. A. (2001). Learning Spanish as a second language: Learners' orientations and perception of their teachers' communication styles. Language Learning, 51(1), 107144. Retrieved from

https://www.researchgate.net/publication/228911033_Learning_Spanish_as_a_Secon d_Language_Learners'_Orientations_and_Perceptions_of_Their_Teachers'_Communic ation_Style

Parijat, P., \& Bagga, S. (2014). Victor Vroom's Expectancy Theory of Motivation - An Evaluation. International Business Journal of Business and Management, volume No. VII September - 2014 Issue 9. https://www.irjbm.org

Pierre, E., \& Oughton, J. (2007). The affective domain: Undiscovered country. College Quarterly, 10 (4), 1-7. Retrieved from https://eric.ed.gov/?id=EJ813766

Pintrich, P. R., \& De Groot E. V. (1990). Motivational and self-regulated learning components of classroom academic performance. Journal of Educational Psychology, 82(1), 33-40. Retrieved from https://psycnet.apa.org/doi/10.1037/0022-0663.82.1.33

Porter, L. W., \& Lawler, E. E. (1968). Managerial attitudes and performance. Homewood, IL: Irwin-Dorsey. 
Ranjha, M. I., Asghar, S. A., and Yasmin, S. (2021) Demotivating factors in the foreign language learning: An analysis of past studies. Pakistan Social Science Review. 5(3),325-338. doi:10.35484/pssr.2021(5-III)24

Reinharth, L., \& Wahba, M. (1975). Expectancy theory as a predictor of work motivation, effort expenditure, and job performance. Academy of Management Journal, 502-537. http://journals.aom.org/doi/abs/10.5465/255682

Ryan, R. M., \& Deci, E. L. (2020). Intrinsic and extrinsic motivation from a self-determination theory perspective: Definitions, theory, practices, and future directions. Contemporary Educational Psychology, 61, Article 101860. https://doi.org/10.1016/j.cedpsych.2020.101860

Ryan, R. M., \& Deci, E.L. (2000). Self-determination theory and the facilitation of intrinsic motivation, social development, and well-being. American Psychologist. 55(1), 68-78. Retrieved from https://uvi.edu

Sekaran, U. (2009) Research method for business: A skill building approach (4th ed.), Wiley India, New Delhi. Retrieved from https://www.goodreads.com/book/show/1104240.Research_Methods_for_Business

Sekaran, U., and Bougie, R. (2016) Research methods for business: A skill-building approach. (7th ed.), Wiley \& Sons, West Sussex. Retrieved from https://www.wiley.com/enus/Research+Methods+For+Business\%3A+A+Skill+Building+Approach\%2C+7th+Edition -p-9781119266846

Skinner, Ellen \& Belmont, Michael. (1993). Motivation in the classroom: Reciprocal effects of teacher behavior and student engagement Across the School Year. Journal of Educational Psychology. 85. 571-581. 10.1037//0022-0663.85.4.571

Steinmayr, R., Weidinger, A. F., Schwinger, M., \& Spinath, B. (2019). The importance of students' motivation for their academic achievement - Replicating and extending previous findings. Frontiers in Psychology, 10, 1730.

https://doi.org/10.3389/fpsyg.2019.01730. Retrieved from https://www.frontiersin.org/articles/10.3389/fpsyg.2019.01730/full

Takase, M., Niitani, M., Imai, T., and Okada, M. (2019). Students' perceptions of teaching factors that demotivate their learning in lectures and laboratory-based skills practice. International Journal of Nursing Sciences 6: 414-420.

https://doi.org/10.1016/j.ijnss.2019.08.001

Tolman, E. C. (1959). Principles of purposive behavior. In S. Koch (Ed.), Psychology: A study of science, volume 2 (pp. 92-157). New York: McGraw-Hill.

Vroom, V. H. (1964). Work and motivation. San Francisco, CA: Jossey-Bass.

Wigfield, A., \& Eccles, J.S., (2000). Expectancy-Value Theory of Achievement Motivation. Contemporary Educational Psychology, 25 (1), 68-81. Retrieved from https://www.sciencedirect.com/science/article/pii/S0346251X19301204?casa_token= NI14zitwvGgAAAAA:hejtOmzs-

X91WtYos1kKa4sPjwzt5NB0RhiKLyw_ArFmRcS2FOfn2Lxz7yA5rYPHftOLgyU9UI4

Wigfield, A., \& Eccles, J. S. (2000). Expectancy value theory of achievement motivation. Contemporary Educational Psychology, 25: 68-81. Retrieved from https://www.sciencedirect.com/science/article/pii/S0361476X99910159

Wigfield, A., \& Eccles, J.S. (2002). The development of competence belief, expectancies for success, and achievement values from childhood through adolescence. In Wigfield, A \& Eccles, J.S (Eds.) Development of achievement motivation. A volume in educational psychology series. San Diego: Academic Press. 
Wlodkowski, R. J. (1999). Enhancing adult motivation to learn: A comprehensive guide for teaching all adults. United States of America: John Wiley \& Sons, Inc.

Wolters, C. A., \& Pintrich, P.R. (1998). Contextual differences in student motivation and selfregulated learning in mathematics, english, and social studies classrooms. Instructional Science, 26: 27-47. Retrieved from https://umich.edu. 